
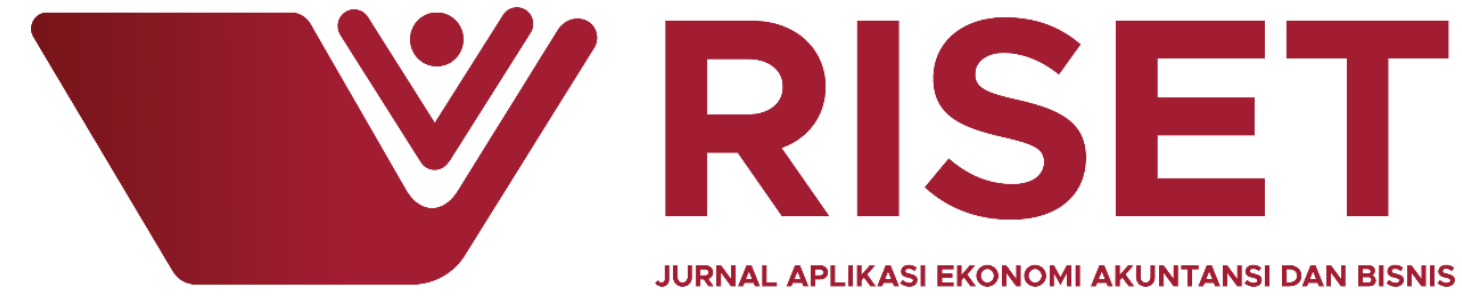

JURNAL APLIKASI EKONOMI AKUNTANSI DAN BISNIS

\title{
THE EFFECTS OF BANK FUNDS SOURCES ON BANK PROFITABILITY IN INDONESIA STOCK EXCHANGE
}

\author{
Annaria Magdalena' ${ }^{1)}$, Bintang S Marpaung ${ }^{2)}$ dan Indira E $\mathbf{M}^{3)}$ \\ ${ }^{1,2,3)}$ STIE Kesatuan
}

\begin{abstract}
INFO ARTIKEL

The Effects Of Bank

Funds Sources On Bank

Profitability In Indonesia

Stock Exchange

Submitted:

13 - September - 2019

Revised:

16 - September - 2019

Accepted:

17 - September - 2019

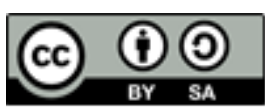

The purpose of this research is to analyze the effects of bank funding sources on bank profitability. The indicators that are used for this research are Capital Adequacy Ratio (CAR), loan received, and thirdparty funds to profitability ratio. A population that is used on this research are commercial banks listed on the Indonesia Stock Exchange. The samples consist of four commercial banks, namely PT Bank Mandiri (Persero) Tbk, PT Bank Rakyat Indonesia (Persero) Tbk, PT Bank Negara Indonesia (Persero) Tbk, dan PT Bank Central Asia Tbk in the period of 2010-2018.

This research uses multiple regression analysis by applying hypothesis tests which are T-test and F test. The results of a partial hypothesis (TTest) show that Capital Adequacy Ratio and loan that received have a significant negative effect on the profitability. Meanwhile, third-party funds have a significant positive effect on profitability. The results of simultaneous hypothesis testing ( $\mathrm{F}$ Test) show that Capital Adequacy Ratio, loans received, and third-party funds have a significant effect on the banks' profitability for the commercial banks that have gone public with the significance level of 0,000 . Meanwhile, $R$ square value $\left(\mathrm{R}^{2}\right)$ on this research is 0,517 or $51,7 \%$, and the rest is $48,3 \%$ affected by other factors that are not considered in this research.
\end{abstract}

Keywords: CAR, loan received, third-party funds, ROA.

Email : anna.jkt29@yahoo.com "),

\section{INTRODUCTION}

Every business entity, whether in the form of a limited liability company (PT), a foundation, or any other form of business entity, has the same goal, namely to obtain the maximum benefit. The benefits successfully obtained are not only used to finance the organization's operations, such as paying salaries and other expenses, but they are also used to develop the organization through various activities in the future. Each 
organization has its own traits or characteristics so that its management must be adjusted to the characteristics. One of the characteristics that distinguish one organization from the rest is the management between companies that sell products in the form of goods with companies that sell products in the form of services, such as companies engaged in banking or better known as banks.

Banks are companies that provide financial services for all levels of society. For financing its business activities, a bank needs a number of funds. The funds for financing bank operations can be obtained from various sources, among others own capital. Capitalization shows the ability of a bank to maintain sufficient capital and the ability of bank management to identify, monitor, and control risks that arise and might affect the amount of bank capital (Prastiyaningtyas, 2010). If a bank has sufficient capital, the bank's operations can be run smoothly. The indicator used to measure capital adequacy is the Capital Adequacy Ratio (CAR).

The next sources of funds are loans or from other institutions. These sources of funds are likely to be more expensive than the bank's own capital. They are temporary because they only function as extra or additional funds if their own capital or derived from the wider community happen hardship in accumulating the funds. The funds derived from the wider community are the most important funding sources for banks; they are easy to obtain and widely available in public. The funds can originate deposits such as savings accounts, checking accounts, and deposits accounts. The higher a bank's ability to raise funds, the greater the opportunity for banks to channel the fund in the form of loans. It means the more likely the bank earns a profit /profitability. In this study, the profitability of banks will be measured by using return on assets (ROA). According to (Tandelilin, 2010) ROA illustrates the extent to which the ability of assets owned by companies can generate profits. ROA is important for banks because it is used to measure the effectiveness of a company in generating returns from the use of assets owned. The higher the ROA, the greater the level of profit achieved the better the bank's condition and the bank's position if it is viewed in terms of asset utilization (Dendawijaya, 2009).

Some researches related to the effects of bank funding sources on bank profitability can be stated as follows: The research conducted by (Sukma, 2013) which examined the influence of third-party funds, capital adequacy and credit risk on the profitability (of banking companies listed on the IDX), found that third-party funds and capital adequacy did not affect the profitability, while credit risk affected profitability in the banking business. In contrast, the research conducted by (Sari, 2015) which examined the analysis of the influence of third-party funds, CAR and LDR on bank profitability, found that third-party funds did not have a significant negative effect on the ROA. On the other hand, the capital adequacy ratio had a positive and significant effect on the ROA, while the LDR had a positive and significant effect on profitability. Based on the above phenomena, this research will focus on "The Impacts of Bank Funds Sources on Bank Profitability."

\section{LITERATURE REVIEW}

According to the Republic Indonesia Act No.10 of 1998 on Banking, the bank is a business entity that collects funds from the public in the form of savings and channels them to the public in the form of credit and other forms in order to improve the living standards of the people. According to (Kasmir, 2008), the bank is a financial institution whose main activity is raising funds from the community and channeling the funds back 

ROA.

to the community and providing other services. Further, according to (Kasmir, 2014), bank's fund's sources is the bank's endeavor in raising funds to finance its operations, such as 1) The funds come from the bank itself. This funding source is the source of funds from the capital itself. Own capital means the paid-up capital of its shareholders. The disbursement of funds itself consists of capital deposits from shareholders, bank reserves, bank profits that have not been shared. 2) Funds come from the wider community. This funding source is the most important source of funds for bank operations, and it is a measure of a bank's success if it is able to finance its operations from other sources of funds. The source of funds from outside the community can take the form of a) checking accounts, b) savings accounts and c) deposits accounts 3) Funds sourced from other institutions. This third source of funds is additional if banks experience difficulties in finding the first and second sources of funds above. A bank obtains the funds from this source, among others a) Liquidity Credit from Bank Indonesia, which is a credit given by Bank Indonesia to banks experiencing liquidity problems. b) Interbank loan (call money), usually it is a loan which is granted to banks that suffered defeat in the clearinghouse. These loans are short term with relatively high interest. c) Loans from foreign banks, which are loans obtained by banks from abroad. d) Money market securities (SBPU). In this case, the bank issues securities and then trades them to the interested parties, both financial and non-financial companies.

The bank's capital position is so important because capitalization is used to measure the bank's ability to meet its long-term obligations or the bank's ability to meet obligations in the event of liquidation (Dendawijaya, 2009). Thus, with the capital contributions from their shareholders, people will believe it to deposit funds. Bank Indonesia requires bank capital calculations using the CAR.

CAR is a ratio that shows how extent all bank assets that contain risks (loans, investments, marketable securities, and other bank bills) are financed from the bank's own capital funds, in addition to obtaining funds from sources outside the bank, such as public funds, loans (debt) and other sources (Dendawijaya, 2009). In other words, CAR is a bank's performance ratio to measure the adequacy of capital owned by banks to support the assets that contain or generate risk such as loans.

The CAR amount of a bank can be calculated using the following formula.

$$
\mathrm{CAR}=\frac{\text { Capital }}{\text { Risk }- \text { Weighted Assets }} \times 100 \%
$$

The higher the CAR, the better the bank's ability to bear the risk of any risky credit or productive assets.

The CAR calculation is based on the principle that every investment that contains a risk must be provided a certain amount of capital to the amount of investment. The following is an evaluation criterion based on CAR component ranking. 
Table 1

The Criteria Matrix of CAR Component Assessment

\begin{tabular}{|l|l|l|}
\hline Ratio & Ranking & Predicate \\
\hline CAR $\quad 12 \%$ & 1 & Very good \\
\hline $9 \% \quad$ CAR $<12 \%$ & 2 & Good \\
\hline $8 \% \quad$ CAR $<9 \%$ & 3 & Adequate \\
\hline $6 \% \quad$ CAR $<8 \%$ & 4 & Poor \\
\hline CAR $6 \%$ & 5 & Very poor \\
\hline
\end{tabular}

Source: Bank Indonesia Circular Letter No. 13/24/DPNP/2011

States that it is an obligation for a bank to provide a minimum capital of 8 percent. If the capital is less than 8\%, the bank will get sanctions from Bank Indonesia. Furthermore, (I. W. Sudirman, 2013) asserts that risk-weighted assets (RWA) is the amount of the risk of balance sheet assets and off-balance sheet bank. Balance sheet assets and administrative assets are weighted according to predetermined risk weighting levels. Each item in an asset is given a weight, the amount of which is based on the level of risk contained in the asset itself or the class of customers or the nature of the collateral. The risk weight is between $0-100 \%$ depending on the level of liquidity. The more liquid the asset is, the smaller the risk weight. Supervision regarding the provisions on RWA is to ensure that the maximum RWA is based on weighting set by Bank Indonesia and to control the growth of bank assets that provide high returns with low risk.

According to (Hasibuan, 2009) there are several steps in calculating the minimum capital supply, as follows:

- The RWA of balance sheet assets is calculated by multiplying the nominal value of each asset concerned by the risk weight of each item of the balance sheet assets.

- The RWA of administrative off-balance assets is calculated by multiplying the nominal value of the administrative account concerned with the risk weight of each account post.

- Total RWA = RWA balance sheet assets + RWA administrative assets.

- The bank's capital ratios are calculated by comparing the bank's capital (core capital + additional capital) and total RWA.

For more details, risk weighting of bank assets are presented as follows:

Table 2

The Risk Weight of Bank Assets

\begin{tabular}{|c|l|c|}
\hline NO & \multicolumn{1}{|c|}{ ACCOUNT } & Risk Weight \\
\hline 1 & $\begin{array}{l}\text { 1. Cash } \\
\text { 2. Bank Indonesia Certificate or SBI }\end{array}$ & $0 \%$ \\
& $\begin{array}{l}\text { 3. Credit with SBI collateral, Savings and Deposits } \\
\text { blocked at the relevant bank, gold collateral. } \\
\text { 4. Credit to the government. }\end{array}$ & \\
\hline 2 & $\begin{array}{l}\text { 5. Current accounts, time deposits, certificates of } \\
\text { deposit, savings, and other bills to other banks. } \\
\text { 6. Credit to or guaranteed by other banks or }\end{array}$ & \\
\hline
\end{tabular}




\begin{tabular}{|c|l|c|}
\hline 3 & $\begin{array}{l}\text { regional governments. } \\
\text { for the purpose of occupancy. }\end{array}$ & $40 \%$ \\
\hline 4 & $\begin{array}{l}\text { 8. Credit to or guaranteed by BUMN or BUMD } \\
\text { 9. Credit to employees or retirees who meet the } \\
\text { requirements: } \\
\text { a. Civil servants, police, military, BUMN, BUMD. } \\
\text { b. Retired civil servants, police, military, BUMN, } \\
\text { BUMD. } \\
\text { c. Employees or retirees are guaranteed with life } \\
\text { insurance from an insurance company that has the } \\
\text { following criteria: } \\
\text { - Business license from the authorized agency } \\
\text { - The financial statements have been audited and } \\
\text { are healthy } \\
\text { - Not a party related to the bank. } \\
\text { d. Payment of insurance or repayment of credit } \\
\text { originates from salary or pension based on a Letter } \\
\text { of Attorney to Withhold Salaries or Pensioners to } \\
\text { the bank. } \\
\text { e. The bank keeps the original letter of appointment } \\
\text { of the employee or the decision letter of retirement } \\
\text { or Pension Parent Registration Card (Karip) and } \\
\text { the debtor's life insurance policy. }\end{array}$ & \\
\hline 5 & Credit to MSE & \\
\hline 6 & $\begin{array}{l}\text { Credit guaranteed by individuals, cooperatives or } \\
\text { other groups or companies }\end{array}$ & \\
\hline
\end{tabular}

Source: Sudirman (2013: 201)

According to (Fahmi, 2013), profitability ratio is the one which indicates the success of the company in generating profits. Potential investors will carefully analyze the smoothness of a company and its ability to make profits. The better the profitability ratio, the better the company's ability to generate profits.

This ratio is used to measure the effectiveness of a company's operations in generating profits. In other words, this ratio is used to measure the ability of bank management to obtain profits as a whole. The ratio in use in measuring profitability in this study is based on Bank Indonesia Circular Letter No. 13/24/DPNP October 25, 2011, namely ROA. The greater the ROA of a bank, the greater the level of profit achieved by the bank and the better the bank's position in terms of asset utilization. This ratio can be formulated as follows (Prawironegoro \& Purwanti, 2009):

$$
R O A=\frac{\text { Profits Before Taxes }}{\text { Total Assets }} \times 100 \%
$$

Based on the theories and phenomena stated above, the hypotheses of this study are: $\mathrm{H}_{1}$ : The funds sourced from the bank's own capital, expressed in capital adequacy ratio (CAR) have a significant positive effect on the profitability.

$\mathrm{H}_{2}$ : The funds sourced from loans received by banks have a significant negative effect on profitability. 
$\mathrm{H}_{3}$ : The funds originating from a third-party in the form of deposits from the public have a significant positive effect on the profitability.

$\mathrm{H}_{4}$ : The funds sourced from the bank's own capital, funds coming from loans and funds from third-party effect simultaneously on the profitability.

\section{RESEARCH METHOD}

The method used in this research is a descriptive method using a quantitative approach, with the aim of making a systematic description related to the facts or nature of the research object by combining the relationships between the variables studied. The variables in this study consist of independent variables stated in CAR, loans received by banks, and third-party funds; in this case, the source of bank funds. Meanwhile, the dependent variable is expressed in the form of ROA.

The population in this research are banking companies already listed on the Indonesia Stock Exchange, with the samples used are the banks in book IV including PT Bank Mandiri (Persero) Tbk, PT Bank Rakyat Indonesia (Persero) Tbk, PT Bank Negara Indonesia (Persero) Tbk, and PT Bank Central Asia Tbk by taking data nine years starting from the period 2010-2018.

The data are collected from the company's financial statements through the GIBEI Kesatuan, as well as the OJK and BI websites. The type of data used in this study is quantitative data, that is data that can be obtained through the financial statements. The source of data used in this study is secondary data obtained through the financial statements. Then the data are tested and analyzed so that a conclusion can be drawn. Hypothesis testing is used to test whether the independent variables have effects on the dependent variable. The hypothesis will be tested using a significance level of 5 percent or 0.05 . If the significance value is $<5 \%$, then the hypothesis is accepted, and vice versa. The analysis method used in this research is the analysis of multiple linear, which is expressed as follows (Ghozali, 2009): $Y=a+b_{1} X_{1}+b_{2} X_{2}+\ldots . .+b_{n} X_{n}+e$.

Note:

$\mathrm{Y}=$ Profitability

$\mathrm{X}_{1}=$ Bank owned funds

$\mathrm{X}_{2}=$ Loans received by the banks

$\mathrm{X}_{3}=$ Third-party funds

$\mathrm{a}=$ Constant

$\mathrm{b}=$ Regression coefficient

$\mathrm{e}=$ Error

\section{RESULTS AND DISCUSSION}

The capital adequacy ratio itself or the CAR must be considered by banks because it is a minimum capital requirement that must be maintained by banks as company performance and as a company development and to accommodate the losses suffered. Following is the level of CAR in four banks in the period of 2010-2018. 
Table 3

The Descriptive Statistics

\begin{tabular}{llllll|} 
& $\mathrm{N}$ & Minimum & Maximum & The mean & Std. Deviation \\
\hline CAR & 36 & 12.75 & 23.95 & 18,6808 & 3,28735 \\
\hline Loan & 36 & \multicolumn{1}{c}{128018.0052024506 .00} & 18140073.44 & 15769725.27 \\
\hline DPK & 36 & 194374685.00 & 944268737.00 & 492629608.3 & 183236540.10 \\
\hline ROA & 36 & 1.91 & 4.74 & 3.4247 & .68926 \\
\hline $\begin{array}{l}\text { Valid } \\
\text { (listwise) }\end{array}$ & N36 & & & & \\
\hline
\end{tabular}

From the table above, it can be seen that the value of $\mathrm{N}$ or the number of samples used amounted to 36, wherefrom the samples which amounted to 36, the minimum CAR value is 12.75 , and the maximum value is 23.95 . While the average value (mean) of 18.68 with a standard deviation of 3,287.

The minimum value of loans received by banks reaches 128,018 (in millions of rupiahs), while the maximum value is 52,024,506 (in millions of rupiahs). The average value of the loans is $18,140,073.44$ (in millions of rupiahs), and the standard deviation is $15,769,725.27$ (in millions of rupiahs).

The minimum value of third-party funds raised by banks is 194,374,685 (in millions of rupiahs), and the maximum value reaches 944,268,737 (in millions of rupiahs). Meanwhile, the average of the total third-party funds raised by banks is $492,629,608.3$ (in millions of rupiahs) with a standard deviation of 183,236,540.1 (in millions of rupiahs).

The minimum value of ROA is 1.91 , and the maximum value is 4.74 . Meanwhile, the average value is 3.42 , with a standard deviation of 0.689 . We notice that the result of the calculation shows that the standard deviation is smaller than the mean. It means that the data distribution is small. Thus, the mean value can be used as a representation of the whole data.

Table 4

The Summary of Impacts on Bank Funding Sources on Bank Profitability

\begin{tabular}{|c|c|c|c|c|}
\hline \multicolumn{2}{|c|}{ Independent Variables } & \multicolumn{3}{|c|}{$\begin{array}{l}\text { Dependent Variable } \\
\text { Bank Profitability }\end{array}$} \\
\hline & $\beta$ & $\mathrm{T}_{\text {count }}$ & $\mathrm{T}_{\text {table }}$ & Sig \\
\hline \multicolumn{5}{|c|}{ Source of Bank Funds } \\
\hline CAR & -0.0680 & $-2,218$ & 2,037 & 0.034 \\
\hline Loan & -0.0034 & $-4,815$ & 2,037 & 0,000 \\
\hline DPK & 0.0027 & 4,235 & 2,037 & 0,000 \\
\hline \multicolumn{4}{|l|}{$\mathrm{R}$ value } & 0.719 \\
\hline \multicolumn{4}{|l|}{ The value of $\mathrm{R}^{2}$} & 0.517 \\
\hline \multicolumn{4}{|l|}{ Adjusted $\mathrm{R}^{2}$ Value } & .471 \\
\hline \multicolumn{4}{|l|}{ Table $\mathrm{F}$ value } & 2,920 \\
\hline \multicolumn{4}{|l|}{ F value calculated } & 11,404 \\
\hline \multicolumn{4}{|l|}{ Sig value } & 0,000 \\
\hline \multicolumn{4}{|l|}{$\boldsymbol{\beta}$ value (constant) } & 4,002 \\
\hline \multicolumn{4}{|l|}{$\mathrm{N}$} & 36 \\
\hline
\end{tabular}


Based on the calculation above, it is known that:

A constant value of 4.002 , meaning that if the source of bank funds is 0 , then profitability $(\mathrm{Y})$ is 4.002 . The regression coefficient $\mathrm{X}_{1 \text { is }}-0.068$, meaning that if other independent variables have a fixed value, and $X_{1}$ has increased by $1 \%$, then profitability (Y) will decrease by 0.68 . Thus, there is a negative relationship between $\mathrm{X}_{1}$ and $\mathrm{Y}$; if $\mathrm{X}_{1}$ rises, then $\mathrm{Y}$ will fall. If the regression coefficient $\mathrm{X}_{2}$ is equal to 0.0034 , it means that there is a negative relationship between $\mathrm{X}_{2}$ and $\mathrm{Y}$, the more it rises $\mathrm{X}_{2}$, the more $\mathrm{Y}$ will decrease. The coefficient of the regression $\mathrm{X}_{3}$ at 0.0027 , it means there is a positive relationship between $\mathrm{X}_{3}$ with $\mathrm{Y}$; if $\mathrm{X}_{3}$ rises, then $\mathrm{Y}$ will further increase as well. The value of $\mathrm{R}$ indicates the number 0.719 , meaning a very strong relationship between $\mathrm{X}_{1}, \mathrm{X}_{2}$, and $\mathrm{X}_{3}$ to $\mathrm{Y}$. Table $\mathrm{R}^{2}$ ( $\mathrm{R}$ Square) shows the number 0.517 , meaning that the percentage contribution of the influence of the independent variable (source of bank funds) to the dependent variable (profitability) is $51.7 \%$, while the remaining $48.3 \%$ is influenced by other variables not included in this research model. $\mathrm{T}_{\text {arithmetic }}>\mathrm{T}_{\text {table }}$, meaning that partially there is no significant effect between $\mathrm{X}_{1}$ and $\mathrm{X}_{2} \mathrm{Y}$. Thus, it can be concluded that partial $\mathrm{X}-{ }_{1}$ and $\mathrm{X}-{ }_{2}$ has no effect on $\mathrm{Y}$ in the banking business. For $\mathrm{X}_{3}$, the $\mathrm{e}_{\text {calculated }} \mathrm{T}$ value $>\mathrm{T}_{\text {table }}$, then partially there is a significant influence between $\mathrm{X}_{3}$ and $\mathrm{Y}$. Thus, third-party funds $\left(\mathrm{X}_{3}\right)$ partially affect the profitability of the banking business. $F_{\text {count }}>F_{\text {table }}$ or $11.404>2.920$, meaning that there is significant influence between bank funding sources $\left(\mathrm{X}_{1}, \mathrm{X}_{2}, \mathrm{X}_{3}\right)$ jointly to profitability (Y). Thus the sources of bank funds together affect the profitability of the banking business.

Thus, it can be said that this result is not consistent with the hypothesis $\mathrm{H}_{1}$, which states that the capital from the banks themselves (CAR) has a positive and significant effect to the profitability. This is because the assets that have the greatest risk is credit. Credit gives the biggest contribution to income for the bank, so if the credit rises, the bank income will rise, or ROE or ROA will increase. The increase in credit will certainly increase the total RWA, which means it will reduce CAR. Thus, if CAR rises, ROE or ROA will decrease, and vice versa. For hypothesis, $\mathrm{H}_{2}, \mathrm{H}_{3}$, and $\mathrm{H}_{4}$ are in conformity with the hypotheses in this study.

\section{CONCLUSION}

Based on the results of the analysis and discussion, it can be concluded as follows: The funds sourced from bank's own capital and funds sourced from injection have a significant but negative effect on the profitability. The funds derived from thirdparty proven affected significantly but positively on the profitability. The results also show that the funds from the bank's own capital, funds from loan received by the bank, and funds sourced from third-party simultaneously affect the profitability. The varied sources of banks' funds (the bank's own capital, loans received, and third-party fund) have a simultaneous effect on the profitability of $51.7 \%$, thus remaining influenced by variables not included in this research. The results of this study are not in accordance with hypothesis $\mathrm{H}_{1}$. Meanwhile, the hypotheses $\mathrm{H}_{2}, \mathrm{H}_{3}$, and $\mathrm{H}_{4}$ are in accordance with the hypotheses in this study. 
Annaria Magdalena ${ }^{1)}$, Bintang $S$ Marpaung ${ }^{2)}$ dan Indira $E M^{3)}$. CAR, loan received, third-party funds, ROA.

\section{REFERENCES}

Dendawijaya, L. (2009). Manajemen Perbankan. Bogor: Ghalia Indonesia.

Fahmi, I. (2013). Pengantar Pasar Modal. Bandung: Alfabeta.

Ghozali, I. (2009). Aplikasi Analisis Multivariate dengan Program SPSS. Semarang: Badan Penerbit Universitas Diponegoro.

Hasibuan, M. S. P. (2009). Dasar-dasar Perbankan. Jakarta: Bumi Aksara.

Kasmir. (2008). Bank dan Lembaga Keuangan Lainya (Edisi Revi). Jakarta: PT. Raja Grafindo Persada.

Kasmir. (2014). Dasar Dasar Perbankan (Edisi Revi). Jakarta: PT. Raja Grafindo Persada.

Prastiyaningtyas, F. (2010). FAKTOR-FAKTOR YANG MEMPENGARUHI PROFITABILITAS PERBANKAN. Semarang.

Prawironegoro, D., \& Purwanti, A. (2009). Akuntansi manajemen (Edisi 2). Jakarta: Mitra Wacana Media.

Sari, Y. A. N. (2015). ANALISIS PENGARUH DANA PIHAK KETIGA, CAR DAN LDR TERHADAP PROFITABILITAS BANK (Pasca Penerapan IFRS). Sekolah Tinggi Ilmu Ekonomi Perbanas Surabaya.

Sudirman, I. W. (2013). Manajemen Perbankan - Menuju Bankir Konvensional yang Profesional (Edisi Pert). Jakarta: Kencana Prenada Media Grup.

Sudirman, W. (2013). Menejemen Perbankan - Menuju Bankir Konvesional Yang Provesional. Jakarta: Kencana Prenada Media Grup.

Sukma, Y. L. (2013). Pengaruh Dana Pihak Ketiga, Kecukupan Modal Dan Risiko Kredit Terhadap Profitabilitas (Perusahaan Perbankan yang Terdaftar di BEI). Jurnal Akuntansi. Padang.

Tandelilin, E. (2010). Portofolio dan Investasi Teori dan Aplikasi (edisi pert). Yogyakarta: Kanisius. 